\title{
Analysis of Teacher's Readiness For 2013 Curriculum Thematic Learning in SD Negeri 04 Kriyan Kalinyamatan Jepara
}

\author{
Zuli Agustin Rahmawati1 ${ }^{*}$, Moh Aniq $\mathrm{KHB}^{2}$, Diana Endah $\mathrm{H}^{3}$
}

1,23 Pendidikan Guru Sekolah Dasar, Fakultas Ilmu Pendidikan, Universitas Pgri Semarang

A R T I C L E I N F O

Article history:

Received 19 February

2019

Received in revised

form

28 March 2019

Accepted 18 April 2019

Available online 30 May

2019

Keywords:

readiness of teachers in the 2013 curriculum

thematic learning

\section{A B S T R A C T}

This research was motivated by the readiness of teachers in the implementation of the 2013 curriculum thematic learning at SD Negeri 04 Kriyan Kalinyamatan Jepara. The problem in the research is "how is the readiness of the teacher towards the implementation of the 2013 curriculum thematic learning in class I to IV SDN 04 Kriyan Kalinyamatan Jepara?". The purpose to be achieved in this study is to describe the readiness of teachers in the 2013 curriculum thematic learning at SD Negeri 04 Kriyan Kalinyamatan Jepara. The method in this study is descriptive research that uses a qualitative approach, the subjects in this study were principals and teachers of Public Elementary School 04 Kriyan Kalinyamatan Jepara. The data in the research are all related instruments about the readiness of teachers in the 2013 curriculum thematic learning at SD Negeri 04 Kriyan Kalinyamatan Jepara. Sources of data obtained through questionnaires, observation, interviews and documentation. Checking data by extending observations, increasing perseverance, triangulating data, peers, holding member checks. while the data analysis techniques go through the stages of data reduction, data presentation, and verification / conclusion. The results of this study indicate that according to the observations I made to different teachers and classes 5 respondents were ready to carry out the 2013 curriculum thematic learning which can be seen from the range of scores that I have analyzed, namely 5 respondents get a range of scores A (Very Good) with scores between $90 \leq A \leq 100$ from the process of implementing learning and learning instruments. Become a researcher through observasil results from the assessment of learning devices and learning implementation instruments. This is to measure the readiness of teachers in the 2013 curriculum thematic learning at SD Negeri 04 Kriyan Kalinyamatan Jepara. Based on the results of this study, the suggestions that can be conveyed are that teachers are more able to increase the creativity of thematic learning with more challenging and maximum readiness in the 2013 curriculum thematic learning process so that it can run well. 


\section{Introduction}

The development of science and technology has brought changes to all aspects of human life, where the problems that arise are resolved by efforts to master the science to increase human resources. Therefore, improving the quality of human resources is a reality that must be carried out in a planned, directed, creative, effective, and efficient manner in the development process facing competition to run the globalization era (Wangid, MN, Mustadi, A Ervina, VY, \& Arifin, S., 2014: 176).

The development of science and technology helped the education today. Sudarno (in Djamarah, 2010: 2) improving the quality, release, and effectiveness of education as a national demand in line with the development and progress of the community, have significant implications in educational programs and school curricula. The learning objectives of the curriculum program at school can be achieved well if the program is clearly designed.

In other parts, Sudarno (in Drost 1999: 1) states from the word paedagogogues, paedagogogus, paedagogia that later came the term pedagog which means educator, pedagogy which means educational change, and paedagogiek which means education. Educate in Latin educare derived from e-ducare which means herding out, human formation or human glorification.

In addition, the experts also stated that education also through education. Sudarno (in Drijarkara 1980: 4) states that education is a scientific thought about the reality that we call education (educating and being educated). Scientific thinking is critical, methodical, and systematic.

In Indonesia, several curriculums changed, the curriculum was arranged to one or more curriculum theories, and curriculum explained from certain educational theories. The curriculum can be seen as a concrete plan for the application of an educational theory. Understanding the curriculum continues to development of various things that must be carried out and become a school assignment. According to the Indonesian dictionary (1990: 4479) states the word curriculum is a noun that has two meanings. First, the set of subjects taught at educational institutions, and secondly the set of courses on specific areas of expertise. In another section Mulyasa (2016: 46) argues that the curriculum is a design and regulation of goals, basic competencies, standard material, and learning outcomes, as well as the methods used as guidelines for organizing learning activities to achieve basic competencies and educational goals.

From the understanding of the curriculum according to other experts such as Mulyasa (in Taba 1962: 3) states by adding needs analysis and material selection so that the curriculum strengthens statement of purpose which refers to the needs analysis, selection, and organizing material, management of learning activities and assessment of learning outcomes.'

In education that involves the education curriculum, there is a learning process that involves teachers and students. Therefore many experts who put forward the notion of learning one of them Mulyasa (in WS Winkel 2002: 4) states that a mental activity that takes place in mental activity that takes place in active interaction between a person and the environment, and produces changes in knowledge, understanding, skills, and the value of attitudes that are constant and trace. In addition, Mulyasa (in Bloom 1979: 89) stated about the learning outcomes taught as being able to absorb the meaning of the material or material being studied. Bloom's understanding is how much students are able to accept, absorb, and understand the lessons given by the teacher to students or to what extent students are able to understand and understand what they are reading, seeing, experiencing, or feeling in the form of research or direct observation he did.

In education, the existence of the role and function of the teacher is a significant factor. The teacher is the most important part in the teaching and learning process, both in formal and informal education. Therefore, in every effort to improve the quality of education in the country, it cannot be separated from various matters related to the existence of the teacher itself. In addition the teacher also plays an important role in the pursuit of teachers one of the intermediaries of students to understand learners from the curricula that have been determined by the minister of education. In this era of globalization, the curriculum used in primary school education is the kurikulum 2013 (Mulyasa 2016: 53).

Kruikulum 2013 has been applied in Kalinyamatan Jepara. One of them is at Kriyan Kalinyamatan Jepara 04 Public Elementary School. The research was carried out at SD Negeri 04 Kriyan Kalinyamatan with teacher centered. In the implementation of the kurikulum 2013 at SD Negeri 04 Kriyan can form character learning for students related to the subjects delivered by the teacher, in addition to the kurikulum 2013 it is also intended to make children more active and think critically and in Kurikulum 2013 teachers are also used for teachers more innovative when teaching by using interesting media and interesting learning methods or models so that students can be interested in learning. SD Negeri 04 Kriyan Kalinyamatan Jepara implemented the 2013 curriculum from 2018 to 2019. In addition, teachers also need to understand the 2013 curriculum both before and after the implementation of the 2013 curriculum at SD Negeri 04 Kriyan. Before the implementation of the 2013 curriculum still use lecture methods or 
models and have not been innovative with less attractive media, teachers also have not mastered Electronic Transaction Information well and teachers still teach with subjects that are still differentiated not being put together like the 2013 curriculum. In 2013 curriculum teachers use more interesting models or methods so that students can be interested in learning that takes place not only monotonous by listening to teachers who teach in front of the class, besides that teachers can master the Electronic Transaction Information well although not all the teacher can use computer well. In this thematic learning the teacher teaches with subjects made in one theme that has been determined by the minister of education. SD Negeri 04 Kriyan applies the 2013 curriculum besides that thematic learning has also been applied in low (1-3) and high classes (4-5). According to Maisyaroh (in Zulkarnain: 219) that the problem of teachers in implementing the 2013 curriculum is achieving standard content. The teachers lack understanding of the basic framework and structure of the curriculum, insufficient time because the contents are too broad for standard process with having difficult in developing lesson plans, the application of scientific learning, thematic integrated, constructivist, media that use laptops and LCD and the achievement of standard competency, difficult in integrating character education in learning. Difficult in developing attitudes, knowledge and skills in an integrated manner while the last in the assessment standards, difficult in making test and compile non-test instruments because there are too many students in the study group.

\section{Methods}

Research Approach

This approach is a descriptive study that uses a qualitative approach.

\section{Research Settings}

This research was conducted at SDN 04 Kriyan Kalinyamatan Jepara located in Desa Kriyan RT 05 RW 01 Kalinyamtan Kabupaten Jepara. The reason why the researchers chose this location because SDN 04 Kriyan conducted thematic learning in the 2013 curriculum which had only been running for one year.

Research Schedule

This research was conducted in the even semester of the 2018/2019 school year on 25 April 2019 30 April 2019 and carried out the research at 7:00 to 12:00

Research Subjects

The subjects of the study were the Principal and teacher at SDN 04 Kriyan Kalinyamatan Jepara.

\section{Result And Discussion}

This discussion seeks to answer more broadly about research questions or describe and compare field findings with existing theories. This discussion includes a series of processes experienced by respondents to finally describe the implementation of the 2013 curriculum at SDN 04 Kriyan Kalinyamatan Jepara. Nova Agustina in Mulyasa (2013: 136) argues that "implementation or often also called implementation is a process that provides certainty that learning programs already have the human resources and facilities and targets needed in implementation, so that competence, character and achieve desired goals". The implementation that has been carried out in this research is the readiness of the teacher towards the 2013 curriculum thematic learning.

To know the respondents well prepared in the 2013 curriculum thematic learning the researcher made the following range of scores.

Table 1. Range Of Scores

\begin{tabular}{ll}
\hline Level & Grade \\
\hline Very Good (A) & $90 \leq \mathrm{A} \leq 100$ \\
Good (B) & $75 \leq \mathrm{B}<90$ \\
Precisely (C) & $60 \leq \mathrm{C}<74$ \\
Less (K) & $<60$ \\
\hline
\end{tabular}

According to the results of observations I made on different teachers and classes 5 respondents were ready to carry out the 2013 curriculum thematic learning that can be seen from the range of scores 
that I have analyzed, 5 respondents got Very Good between $90 \leq \mathrm{A} \leq 100$ of the process of implementing learning and instruments. So researchers through the results of observations of the assessment of learning tools and instruments for implementing this learning to measure the readiness of teachers in the thematic learning curriculum 2013 at SD Negeri 04 Kriyan Kalinyamatan Jepara.

From the results of observations at SD Negeri 04 Kriyan I have analyzed the teacher's will be easier in making assessment instruments for each student and can carry out learning that is already related to the 2013 thematic learning curriculum. And all respondents were ready in the 2013 curriculum thematic learning process as recommended. This evidenced through several findings in the field conducted by researchers through questionnaires, observations, interviews, and documentation. It supported the readiness of teachers in the 2013 curriculum thematic learning that has been going well, the results of interviews with school principals, but the respondents complained that there are teachers who still carried out the curriculum KTSP even though a new curriculum has been provided but still carried away KTSP learning curriculum which fulfills, teaching aids that involve learning media are inadequate because in 2013 the curriculum uses a lot of tools such as LCDs and assessment of learning that is too complicated for teachers. This is supported by the results of an interview with Ibu Mastikhah, S.Pd.SD who mentioned that the 2013 curriculum requires teachers to be more able to use technology as well as when teaching teachers to use LCDs for the learning process while in SDN 04 Kriyan many teachers are old and lazy to use the LCD.

From the results of discussions with related research conducted by 2 lecturers from the University of PGRI Semarang Filia and Yusuf he said that the 2013 curriculum was better than the KTSP curriculum besides that in the 2013 curriculum emphasizing active and creative learning both students and teachers and a study that used three cognitive, affective and psychomotor domains seen from core competencies such as religious, knowledge, attitudes, and skills that are in the curriculum. The subjects must contribute to the formation of attitudes, skills and knowledge by using media and learning resources and methods that are appropriate then the subjects of core competencies will be achieved well. Therefore, the teachers of SDN 04 Kriyan Kalinyamatan Jepara were good in delivering material and in accordance with core competencies from religious aspects, knowledge, attitudes and skills, but in writing and assessment still not in accordance with the 2013 curriculum.

Nova Agustina in Kusnadar (2013:2) the main tasks of teachers in learning include: (1) Arranging learning programs, (2) Conducting learning programs (3) Conducting assessment of learning outcomes, (4) Conducting analysis of learning outcomes, (5) Conducting programs follow-up.

In the 2013 curriculum there are lots of advantages and disadvantages in learning and assessment, but the government must also convey more information about the 2013 curriculum and pay attention to completeness to teach so that educators will be more optimal in implementing the 2013 curriculum well.

\section{Conclussion}

From the results of the research and discussion contained in chapter IV and the 2013 curriculum thematic learning problems at SD Negeri 04 Kriyan it was stated that the teachers at the elementary school were ready. Judging from the results of observations that I did through 5 teacher respondents who got very good ratings from the results of the implementation of learning and learning assessment instruments such as teachers have made lesson plans well, how to apply assessments to lesson plans is good, use learning media properly, and methods innovative learning involving cognitive, affective and psychomotor aspects. So the readiness of teachers in 2013 thematic learning curriculum at SD Negeri 04 Kriyan Kalinyamatan Jepara has been going well.

Based on the conclusions above, then to optimize the implementation of the 2013 curriculum, the researchers provide suggestions, i.e

1. Teachers are better able to explore the 2013 curriculum both in terms of teaching, and assessment, can also be through training or socialization about the curriculum that has taken place at the district level.

2. Teachers are better able to utilize LCD media and computers properly because in the current era of globalization teachers are required to be able to use electronic media because students tend to like things that students have never gotten in class.

3. Teachers must be more able to make students interested in using games in every learning so students do not feel bored with the learning system that only teachers speak in front of the class.. 


\section{Reference}

Agustina, N.P. 2016. Analisis Pelaksanaan Kurikulum 2013 di SDN Cipajang 04 Kabupaten Brebes. Skripsi. Semarang:

Akbar,S., A'yun, I., Ferisa, D, Rakyan, S., Widodo, W. 2017. Implementasi Pembelajaran Tematik di Sekolah Dasar. Bandung: PT Remaja Rosdakarya Offset.

Arifin, Z. 2011. Konsep dan Model Pengembangan Kurikulum. Bandung: PT Remaja Rosdakarya Offset.

Daryanto. 2013. Standar Kompetensi dan Penilaian Kinerja Guru Profesional. Yogyakarta: Gava Media.

Hidayat, S. 2013. Pengembangan Kurikulum Baru. Bandung: PT Remaja Rosdakarya Offset.

Ihsan, F. 2011. Dasar-Dasar Kependidikan. Jakarta: PT Rineka Cipta.

Kusdaryani, A., Suyanti,T. M. P., Sudharno, M. A., Suharno, A., Soegeng A.Y. 2009. Pengantar Ilmu Pendidikan. Semarang: FIP IKIP PGRI Semarang.

Maisyaroh, Wildan Z, Arbin J S, Susriyati M. 2014. Masalah Guru Dalam Implementasi Kurikulum 2013 dan Kerangka Model Supervisi Pengajaran. Jurnal Manajemen Pendidikan, 24(3) hal 213-220 (27 Juni 2019 11:34)

Mulyasa, E. 2015. Guru dalam Implementasi Kurikulum 2013. Bandung: PT Remaja Rosdakarya Offset.

Mulyasa, E. 2016. Pengembangan dan Implementasi Kurikulum 2013. Bandung: PT Remaja Rosdakarya Offset.

Puspita H.J. 2016. Implementasi Pembelajaran Tematik Terpadu Kelas VB SD Negeri Tegalrejo 1 Yogyakarta. Jurnal Pendidikan Guru Sekolah Dasar, 9 (5), hal 884 (02 Oktober 2018 16:11)

Soegeng, A.Y. 2018. Filsafat Pendidikan. Yogyakarta: Magnum Pustaka Utama.

Sudharto., Suyati T., Suharno A., Kusdaryani W., Soegeng A.Y. 2009. Pengantar Ilmu Pendidikan. Semarang: FIP IKIP PGRI SEMARANG

Sugiyono. 2017. Metode Penelitian Kebijakan. Bandung: Alfabet,cv

Susanto, A. 2016. Teori Belajar dan Pembelajaran di Sekolah Dasar. Jakarta: Prenadamedia Group.

Susilo, Muhammad Joko. 2012. Kurikulum Tingkat Satuan Pendidikan Manejemen Pelaksanaan dan Kesiapan Sekolah Menyongsongnya. Yogyakarta: Pustaka Pelajar Offset.

Suyitno, Mudzanatun., Dwi, S.A. 2017. Kajian Kurikulum Bahasa Indonesia Sekolah Dasar. Semarang: UPT Penerbit Universitas PGRI Semarang Press.

Wangid M, Mustadi A, Ervina V, Arifiin. 2014. Kesiapan Guru Sd dalam

Pelaksanaan Pembelajaran Tematik Integratif pada Kurikulum 2013 di DIY. Jurnal Prima Edukatf, 2 (2), hal 175 (02 Oktober 2018 16:18)

Widyastono, Herry. 2014. Pengembangan Kurikulum di Era Otonomi Daerah. Jakarta: PT Bumi Aksara http://dapo.dikdasmen.kemdikbud.go.id/guru/2/032000 (27 Juni 2019 11:34) 